\title{
A büntetőjogi elévülés határidejének megállapításáról
}

\author{
Determining the Period of Criminal Legal Limitation
}

\begin{abstract}
ABSZTRAKT
Tanulmányom témája a büntethetőséget megszüntető elévülés. Dolgozatomban először általánosságban szólok az elévülésről, a büntető törvénykönyvben elfoglalt helyéről, illetve jogelméleti igazolásáról. Ezt követően egy jogtörténeti kitekintést adok, bemutatva az első büntető törvénykönyvünkben foglalt elévülési rendszert. Ismertetem az elévülési idő hatályos szabályait, majd az elévülés érvényre jutásával összefüggésben a büntetőeljárási törvény vonatkozó rendelkezéseit, végezetül dolgozatom utolsó részében de lege ferenda javaslattal vonom le annak következtetéseit.
\end{abstract}

Kulcsszavak: büntetőjog, büntethetőséget megszüntető ok, elévülés, elévülési idő

\begin{abstract}
In my essay I examine the statutes of limitation in criminal law. Firstly, I give a general description of limitation, of its position in the Criminal Code and of its legal theory. Secondly, I review the legal history of limitation demonstrating the system of limitation in our first criminal code. After that, I outline the regulations concerning the period of limitation and then describe the way limitation is enforced in the statute of criminal procedure. Finally, I draw the conclusions of my essay in the form of a proposition de lege ferenda.
\end{abstract}

Keywords: criminal law, grounds for exemption from criminal responsibility, statutes of limitation, period of limitation

A hétköznapi élet tapasztalata, hogy vannak dolgok, amiket bizonyos idő eltelte után már nem érdemes bolygatni. Határidők eltelnek, események a feledés homályába merülnek, és gyakran szúrós szemmel nézünk azokra, akik régmúlt sérelmeket emlegetnek fel hosszú idő után. Érezzük, az idő múlásának van jelentősége a mindennapi életben - és nincs ez másként a jog területén sem. Az idő folyásából fakadó elévülés témájával a jognak talán valamennyi területe foglalkozik, hol részletesebben, hol kevésbé tüzetesen; annak megfelelően, hogy az az adott jogviszonyokban milyen jelentőséggel vagy gyakorisággal bír. Nem kivétel ez alól a büntető anyagi jog sem. Az első magyar büntetőkódex óta törvényben is szabályozott jogintézmény a tág értelemben vett büntetőjog valamennyi ágában megtalálható: a büntető anyagi jogi elévülés az eljárásjog területén fejti ki hatását, de azt a büntetésvégrehajtási jog is ismeri.

* Dr. Hadházi Dávid, PhD-hallgató, Debreceni Egyetem Marton Géza Állam- és Jogtudományi Doktori Iskola, e-mail: had.dave@gmail.com. 
Bár lassan százötven éve már kodifikáltan is jelen van jogrendszerünkben az elévülés, a témával a büntetőjogi irodalom utoljára nagyjából egy évszázada foglalkozott átfogóan. Pedig a jogintézmény szabályozása azóta is jelentős változásokon esett át. A büntethetőséget megszüntető elévülés komplex vizsgálatát a jelen tanulmányban nekem sincs lehetőségem elvégezni, így írásom fókuszába az elévülési idő egyes kérdéseit állítom.

\section{Néhány szóban az elévülésről}

A történelmi fejlődés során az állam büntetőhatalmi igénye egyre jobban kiteljesedett, ${ }^{1}$ és a büntetőjog közjogiasodásával kizárólagossá vált az egyén önkényével szemben. ${ }^{2} \mathrm{~A}$ büntetőjogi felelősségre vonás állami hatáskörbe került, a felvilágosodást követően pedig egyre részletesebb szabályozást kapott a büncselekményeket elkövető személyekkel szembeni fellépés, ami büntető törvénykönyvekben és büntetőeljárási kódexekben öltött testet. Az állam nem csak a felelősségre vonás szabályait iktatta törvénybe, hanem azokat a körülményeket is, amelyek fennállása megakadályozhatta azt.

A büntethetőségi akadályok körében a Büntető Törvénykönyvröl szóló 2012. évi C. törvény (a továbbiakban: Btk.) osztályozása alapján megkülönböztetjük a büntethetőséget kizáró vagy korlátozó okokat, a büntethetőséget megszüntető okokat, illetve a büntetőjogi felelősségre vonás egyéb akadályait. Tanulmányom témája, az elévülés, a büntethetőséget megszüntető okok körébe tartozik. A Btk. 25. §-ának b) pontja nevesíti, mégpedig az elkövető halála, a kegyelem, a tevékeny megbánás és a törvényben meghatározott egyéb ok mellett. A jogintézményre vonatkozó részletes szabályokat a Btk. 26-28. §-ai tartalmazzák.

Az elévülés esetén egy időmúláshoz kapcsolódó jogintézményről beszélünk. Az elévülés egy olyan határidő, amely ha eltelik, az valamely jog állami (tipikusan bírósági) úton való érvényesíthetőségének akadályát képezi. A büntetőjog esetében ez a jog - az eljárásjogi legalitás elvéből fakadóan - az állam joga és kötelezettsége ${ }^{3}$ arra, hogy a büncselekmény elkövetőjét megbüntesse, azonban az állam saját magát korlátozza: meghatározott idő elteltével e jogát már nem kívánja érvényesíteni, vagyis az elkövető büntethetősége elévül.

A Btk.-javaslat miniszteri indokolása szerint a büntethetőség elévülése végső soron a jogbiztonságot szolgálja, hiszen a jogintézmény az állam büntetőhatalmi igénye érvényesítésének időbeli korlátozásával biztosítja azt, hogy se a társadalom, se az elkövető ne legyen hosszabb ideig bizonytalanságban afelől, hogy az elkövetett cselekmény miatt a büntetőjogi felelősség megállapításra kerül-e. Az elévülés jogelméleti indoka továbbá, hogy ha a büncselekmény elkövetése és annak megítélése

${ }^{1}$ GeRgI-HoRgos Lívia: A közvád kialakulásának jogtörténeti áttekintése a ius puniendi állami monopóliummá válása folyamatában. Büntetőjogi Szemle, 2014/2., 44-48.

1002 Belovics Ervin-NAgy Ferenc-Tóth Mihály: Büntetőjog I. Általános Rész. HVG-ORAC, Budapest, $2015,26-27$.

${ }^{3}$ PAULER Tivadar: Jog- és államtudományok encyclopaediája. Athenaeum, Pest, 1871, 122. 
között tetemes idő telik el, a kiszabott büntetés kevésbé, vagy talán egyáltalán nem érheti el célját. ${ }^{4}$

Ezzel együtt pedig az elkövető társadalomra veszélyessége is rendszerint csökken. Az időmúlás pedig komplikáltabbá teszi a bizonyítást is: nehezebb lesz a bizonyítékok beszerzése, hiszen azok elenyészhetnek, megsemmisülhetnek; a tanúk emlékezete megkophat, felkutatásuk körülményessé válhat - de a terhelt számára is megnehezül a védekezés. Söt, különösen az enyhítő és mentő körülmények bizonyítása válik terhesebbé az egyén számára, szemben a hatóság rendelkezésére álló széles apparátussal és technikai eszközökkel. ${ }^{5}$ Ezenfelül a méltányosság szempontja sem elhanyagolható, miszerint az elkövetö, ha „esetlegesen már törvénytisztelő életmódot folytat" s cselekménye is feledésbe merült, ne legyen akármeddig büntethető. ${ }^{6}$ Hasonló érvet említett meg Pauler Tivadar már 1869-es Büntetőjogtanában is, hozzáfüzve, hogy nem tanácsos a bíróságokat olyan „vizsgálatokkal terhelni, melyeknek eredménytelensége előrelátható vagy legalább fölötte valószínü."

Az elévülés tehát „az idő múlásához füzött olyan kedvezmény, amely elenyészti az állam büntetőjogi igényét." ${ }^{8}$ Ezzel megszünik az elkövető büntethetősége, és „alanyi joga keletkezik arra, hogy ne lehessen megbüntetni. ${ }^{\prime 9} \mathrm{Az}$ el nem évülő búncselekmények esetében, mivel ezek súlyosabb deliktumok, „az állam fenntartja büntetőigénye érvényesítésének a lehetőségét tekintet nélkül az idő múlására." 10 Hiszen ez utóbbi esetben olyan cselekményekről beszélünk, amelyek „mély nyomokat hagytak az emberiségben, [...] azok az idő múlásával sem törölhetők ki az emlékezetből."11

\section{Az elévülési idő a jogtörténet tükrében}

Az elévülési idő kapcsán érdemes annak hazai jogtörténeti alakulását, különösen az első büntető törvénykönyvbeli szabályozását áttekinteni, ugyanis ez érdekes adalékokkal szolgálhat a hatályos szabályozás vizsgálatához is.

\section{1. „Büntetés van megállapítva” - a konkrét büntetéshez igazodó elévülési idő}

A magyar büntetőtörvénykönyv a büntettekről és vétségekröl címet viselő 1878. évi V. törvénycikk miniszteri indokolása szerint bár az 1843-as büntetőjavaslat tar-

${ }^{4}$ T/6958. számú törvényjavaslat a Büntető Törvénykönyvröl, 2019. április, 219.: https://www.parlament.hu/ irom39/06958/06958.pdf (2021. 03. 12.).

${ }^{5}$ BÉKÉS Imre-FöLdVÁRI József-GÁSPÁR Gyula-ToKAJI Géza: Magyar Büntetőjog általános rész. BM Könyvkiadó, Budapest, 1980, 223.

${ }^{6}$ GöRgÉnYI llona-GuLA József-HoRvÁtH Tibor-JAcsó Judit-LÉvaY Miklós-SÁNTHA Ferenc-VÁRADI Erika: Magyar Büntetőjog Általános Rész. CompLex, Budapest, 2012, 219.

7 PAULER Tivadar: Büntetőjogtan. I. kötet, Pfeifer Ferdinánd, Pest, 1869, 314-315. [a továbbiakban: PAULER (1869)].

${ }^{8}$ BLAskó Béla: Magyar Büntetöjog. Általános Rész. Rejtjel, Budapest-Debrecen, 2016, 270.

${ }^{9}$ BLASKó: i. m., 271.

${ }^{10}$ Btk. miniszteri indokolása, 220.

11 BLASKó: i. m., 271. 
talmazott az elévülésre vonatkozó rendelkezéseket, ${ }^{12}$ azonban az első Btk. hatályba lépése előtt ez a jogintézmény - részben szokásjogi alapon, részben az osztrák Btk.-ból átvett intézményként ${ }^{13}$ - csak alig-alig volt jelen a fennálló jogrendszerben. ${ }^{14}$ Pauler Tivadar egyik munkája ${ }^{15}$ szerint a sajtóvétségek esetében 1848-tól ismert volt az elévülés, és azt egy 1868-as, a polgári törvénykezési rendtartás tárgyában hozott törvény is (a bűnvádi kereset elévüléseként) említette ${ }^{16}-$, ugyanakkor álláspontja szerint annak állandó gyakorlatáról korábban nem beszélhettünk.

A Csemegi-kódex még eltérő terminológiával, "A bünvádi eljárás megindítását és a büntetés végrehajtását kizáró okok" címet viselő IX. fejezetében szabályozta az elévülést. A 105. § alapján kizárta a bünvádi eljárást: 1 . a bünös halála; 2 . a királyi kegyelem; 3. az elévülés. A jogintézményt innentöl kezdve valamennyi törvénykönyvünk szabályozta, a büntetőtörvénykönyv általános részéröl szóló 1950. évi II. törvény (a továbbiakban: Btá.) óta - ugyan a részletszabályokban eltérő, de a jelenleg hatályossal azonos elvek szerint. Az első büntetőkódexünk azonban az elévülés idejére nézve a jelenlegitől egészen eltérő rendszert alkalmazott.

$A z$ 1878. évi V. törvénycikk elévülési határidői - a jelenlegitöl eltérően - nem az absztrakt büntetési tételekhez, hanem a konkrét büntetésekhez igazodtak. Az 1878as Btk. 106. §-a szerint az elévülés húsz év, tizenöt év, tíz év, öt év vagy legalább három év elteltével zárta ki a bűnvádi eljárás megindítását, annak megfelelően, hogy az elkövetett bűntettre vagy vétségre - ahogy a törvényhely fogalmazott - milyen „büntetés van megállapítva.”

\subsection{A korrekcionalizáció}

Az imént idézett szófordulat értelmezése élénk vitát váltott ki a korabeli jogirodalomban, és az szoros összefüggésben állt az úgynevezett korrekcionalizációval. Ennek lényege, hogy maga a törvény - főszabály szerint - nem határozta meg az egyes különös részi tényállásoknál, hogy az adott bűncselekmény bűntettnek vagy vétségnek minősül-e. Ennek mérlegelését a jogalkotó az eljáró bíróra bízta, annak függvényében, hogy milyen konkrét büntetést szabott ki - ettöl függött a bűncselekmény bűntetté vagy vétséggé minősítése. ${ }^{17} \mathrm{Az}$ 1878. évi Btk. 20. §-a sorolta fel

\footnotetext{
12 Lásd FAYER László: Az 1843-iki büntetőjogi javaslatok anyaggyüjteménye. I. kötet, Magyar Tudományos Akadémia, Budapest, 1896, II. Rész, 34-35.

${ }^{13}$ Lásd például a püspökladányi cs. kir. szolgabírói hivatal egy 1854-ben kezdődött büntetőügyét, amelyben a hajdúszoboszlói plébános egy Elek Lydia nevű asszony ellen istenkáromlás vétke miatt tett panaszt (feljelentést), 1858-ig nem történt eljárási cselekmény, majd 1858. március 30-án az iratborítóra ráirták, hogy a cselekmény büntethetősége „a btk. 531. §-a értelmében elenyészett.” MNL HBML IV. 659/d. 2. d. 627. Bü/854. [Idézi BALOGH Judit: A püspökladányi császári és királyi szolgabírói hivatal jogszolgáltató tevékenysége a neoabszolutizmus időszakában - az első lépések az állami bíráskodás felé. In: Megyeri-Pálffi Zoltán (szerk.): A jogszolgáltatás története Püspökladányban, Debreceni Törvényszék, Debrecen, 2021, 62.]

${ }^{14}$ Löw Tobiás: A magyar büntetötörvénykönyv a büntettekröl és vétségekröl (1878:5. tcz.) és teljes anyaggyüjteménye. I. kötet, Pesti könyvnyomda-részvény-társaság, Budapest, 1880, 571.

15 PAULeR (1869): i. m., 317.

16 1848:XVIII. tc. 28. §, 1868:LIV. tc. 322. §.

17 WERNER Rezső: A correctionalisatio elvének alkalmazhatósága. Jogtudományi Közlöny, 1879/2, 9.
} 
a büntetési nemeket, és iránymutatást tartalmazott a büntetendő cselekmények bűntettre és vétségre osztására. Az említett rendelkezés szerint a halálbüntetés, $a$ fegyház és a börtön kizárólag bűntettekre, a fogház pedig kizárólag vétségekre volt alkalmazandó. Az államfogházat, ha öt évnél rövidebb tartamban szabták ki, vétségnek minősülö cselekményre; ha pedig ötévi vagy azon felüli tartamban, büntettnek minősülöre alkalmazták. A pénzbüntetés mint önálló büntetés, kizárólag vétségekre; mint mellékbüntetés, bűntettekre és vétségekre is alkalmazható volt.

Akkor is, ha maga a törvény szövege nevesítette a büntetendő cselekmény büntetti vagy vétségi minőségét, annak végső megállapítása - a kiszabott szankcióhoz igazodva - a bíróra maradt. Így ha a bíróság az elkövetett büntett miatt az enyhítő körülményeket figyelembe véve vétségi büntetést szabott ki (tehát például börtön helyett fogházat), a büntett átminősült vétséggé. ${ }^{18}$

A korrekcionalizáció elve alapvetően határozta meg a büntetéskiszabási gyakorlatot, és voltaképpen a korrekcionalizáció miatt egy, a maitól egészen eltérő szemlélet alakult ki a kor elméleti és gyakorlati büntetőjogászai között. A büntetési tételkerettől lefelé történő eltérés lehetőségét az enyhítő körülmények nyomatékos voltára vagy nagy számára tekintettel már a Csemegi-kódex is biztosította 92. §-ában - és ezzel igen gyakran éltek is a bíróságok. ${ }^{19}$ Ennek eredményeként válhatott a törvény különös része által bűntettnek nevezett bűncselekmény vétséggé. Abból fakadóan pedig, hogy a bủncselekmény típusának meghatározása során központi helyre került a bírói mérlegelés és a deliktumok ítéletbeli minősítése, az ezen a szemponton alapuló megközelítés az elévülés vonatkozásában is kiindulópontnak látszott. Mindez annak volt köszönhető, hogy az adott bủncselekménynek bủntetti vagy vétségi minőségét nem a jogalkotó döntötte el, hanem annak megítélését átengedte a jogalkalmazónak.

\subsection{A korrekcionalizáció és az elévülés}

Mivel az eljáró bíró így a törvényen alapuló erős felhatalmazást kapott, adta magát az a szemlélet, hogy az eljárási elévülés esetében az elévülési idő ne a törvényben rögzített büntetési tételek felső határához igazodjék, hanem a bíró által megállapított (helyesebben: valószínüsített) konkrét büntetéshez. Mint azonban említettem, a jogirodalomban kezdetben vitatott volt, hogy a 1878. évi V. törvénycikk 106. §-ában szereplő „büntetés van megállapítva” szófordulatot miként kell érteni: hogy a bíró által „van megállapítva,” vagy hogy a jogalkotó által a törvény különös részében.

Fayer László egy, a témában írt tanulmányában akképpen vélekedett - a korrekcionalizáció elvére hivatkozva -, hogy a kérdéses szakaszt nem lehet másként érteni,

\footnotetext{
${ }^{18}$ Lásd Belovics et al.: i. m., 191.

19 Lásd FINKEY Ferenc: A magyar büntetőjog tankönyve. Grill Károly Könyvkiadóvállalata, Budapest, 1914, 513. Ahogy Finkey Ferenc is megjegyezte, 1906-ban a törvényszéki szinten indult büntetöügyek közel kétharmada esetében alkalmazták ezt az enyhítő szakaszt, és a járásbírósági szinten is az összes eset 13-14\%-ában. (Ez utóbbi kisebb arány indokát Finkey abban látta, hogy a járásbíróság elé tartozó vétségeknél a speciális minimum egyébként is alacsony volt, így a bíró az enyhítő szakasz alkalmazása nélkül is kellően méltányos büntetést tudott kiszabni).
} 
mint hogy az elévülési idő nem a büntetési tétel felső határához igazodik, hanem a bírónak az elkövetett cselekményt előbb minősítenie szükséges, majd ez alapján megállapítania a „kiérdemlett büntetést,” amihez igazodik az eljárási elévülési idő. S csupán abban az esetben nem tartotta szükségesnek e procedúra lefolytatását, „midőn a bíró az eljárás folyamában meggyőződik [arról], hogy az elévülés a törvényben foglalt maximum szerint is be van már fejezve."20

Angyal Pál A Magyar Büntetőjog Tankönyve címü munkájában hasonlóan foglalt állást, vagyis hogy az 1878-as Btk. hatálya alatt az „elévülési idő a cselekmény konkrét súlya szerint igazodik, tehát nem a törvény által megállapított, hanem a bíróság által hozzávetőleg kiszabandónak vélt büntetés veendő alapul."21

E felfogás azonban korántsem volt annyira egyértelmű a kor jogásztársadalmán belül, ugyanis egyes szerzők - mint például Werner Rezső - a Csemegi-kódex 106. §-át úgy értelmezte, hogy az az absztrakt büntetéshez igazítja az elévülési időt. ${ }^{22}$ Hasonlóan gondolkodott Schnierer Aladár is. ${ }^{23}$

A szakirodalomban végül ez utóbbi álláspont kisebbségbe került, és a bírói gyakorlat is úgy értelmezte, hogy a jogalkotó nem a büntetési tételkeretekhez, hanem a kiszabandó büntetéshez igazította az elévülési határidőt. A bűntettből vétséggé átváltoztatott cselekmények esetében az ezirányú jogalkalmazás mellett a Királyi Kúria 1886-ban az 59. számú döntvényével foglalt állást, melyben kimondta, hogy a vétséggé minősített bủntettre nézve a vétségekre vonatkozó szabályokat kell alkalmazni, illetve hogy „a cselekmény [maga is] olyannak tekintendő, mintha már elkövetésekor is vétséget képezett volna", és ez igaz az elévülés vonatkozásában is. ${ }^{24}$ Tehát az a bíró által megállapított (kiszabandó) büntetés mértékéhez igazodik.

A korrekcionalizációnak az elévülésre ilyen módon történő alkalmazása a büntetések végrehajtásának elévülése kapcsán (melyet akkor még szintén a Btk. rendezett) nem is jelentett különösebb problémát. Hiszen a bíróság kiszabott egy konkrét büntetést, amelyből egyértelmű volt, hogy végrehajthatóságának elévülése hány év elteltével következik be.

Más volt a helyzet viszont az eljárási elévülés esetében: az a büntetőeljárás lefolytatását és a marasztaló ítélet meghozatalát, lényegében a konkrét büntetés kiszabását akadályozta meg. Tehát a bírói fórum nem hozhatott az eljárási elévülést is meghatározó büntetésről érdemi döntést. Így viszont megnehezedett az elévülés kérdésében való állásfoglalás: a bírónak - jogerős ítélet híján - valószínűsítenie kellett egy szankciót, amit akkor szabott volna ki, ha végig lefolytatja az eljárást. És ezen kiszabandó büntetés alapján tudta csak megállapítani, hogy a konkrét bủncselekmény elévült-e vagy sem.

Bár főszabályként a konkrét büntetés alapján kívánták az elévülést meghatározni, némely esetben azonban elkerülhetetlen volt, illetve éppen a könnyebbség indokol-

\footnotetext{
${ }^{20}$ FAYER László: Adalékok a magyar büntető-törvénykönyv magyarázatához XI. - A correctionalisatio elve a m. büntetö-törvénykönyv 106. §-ában. Magyar Themis. 1878/40, 316-317. [a továbbiakban: FAYER (1878)].

${ }^{21}$ ANGYAL Pál: A Magyar Büntetőjog Tankönyve. II. kötet, [s. n.], Budapest, 1943, 77.

22 WeRneR, i. m., 1879/2, 9-11. 1879/3, 17-18.

${ }^{23}$ Idézi FAYER (1878): i. m., 317.

${ }^{24}$ Németh Péter (szerk.): A kir. Curia teljes ülési megállapodásai. Első füzet, Eggenberger-féle könyvkereskedés bizománya, Budapest, 1887, 292-293.
} 
ta, hogy mégis az absztrakt büntetéshez igazítsák azt. Így például amikor a cselekmény már a törvényi tételkeret maximuma szerint is elévült, nem volt szükséges valószínüsíteni egy konkrét büntetést, ${ }^{25}$ az eljárásnak azonban ilyenkor is el kellett jutnia a bírósági szakig.

\subsection{A Csemegi-kódex elévülési modelljének értékelése}

Az egykori modellnek több negatívumát is megemlíthetjük. Egyrészt azzal, hogy az eljárási elévülés kérdésében végsősoron csak a bíró dönthetett, egy rendkívül bonyolult elévülési rendszer jött létre, amely az igazságszolgáltatást is jobban leterhelte. A büntetőeljárás nem fejeződhetett be a nyomozási szakban, hiszen azt le kellett folytatnia a nyomozó hatóságnak, a királyi ügyészségnek vádat kellett emelnie, így az eljárást bírósági szakaszba juttatva, a bírónak kellett végső soron az elévülésben döntenie. ${ }^{26}$

Másrészt a bírónak, ha nem is az eljárási szabályok szerint, de „gondolatban” le kellett folytatnia az egész eljárást, értékelni a bizonyítékokat, mérlegelni az enyhítő és súlyosító körülményeket, és valószínüsíteni egy megfelelő büntetést - hogy ez alapján meghatározhassa: a pulpitusról is lefolytathatja-e az eljárást, vagy az az elévülés miatt marad csak az "elme tárgyalótermében."

Ugyanakkor - eltekintve a konkrét szankcióhoz igazodó elévülési időtől - pozitívumként rögzíthető, hogy a Csemegi-kódex ezzel egy, az igazság eszméjének és a jogbiztonságnak az érvényre jutásához füződő garanciális elemet épített be az elévülési rendszerbe, hiszen az eljárást csak úgy lehetett megszüntetni, ha arról a független igazságszolgáltatás letéteményese, az ügyben eljáró bíró dönthetett.

\section{Az elévülési idő}

A konkrét büntetéshez igazodó eljárási elévülés elvével a Btá. szakított. 1951. január 1-től kezdve ugyanis a Csemegi-kódex trichotóm rendszert követő bủncselekményi felosztását (bủntett, vétség, kihágás) a Btá. monista rendszere váltotta fel (amelynek értelmében minden büncselekmény bűntettnek minősült). Ebből fakadóan a korrekcionalizáció intézménye szükségképpen megszűnt, az ahhoz kötődő elévülési rendszer pedig megváltozott: egy egyszerübb szabályozással a büntethetőség elévülése a különös részi absztrakt büntetésekhez igazodott, bizonyos esetekben azt már a büntetési tétel felső határához kötve [Btá. 25. §]. Ezt a megoldást követte a Magyar Népköztársaság Büntető Törvénykönyvéről szóló 1961. évi V. törvény 31. §-a, majd a Büntető Törvénykönyvröl szóló 1978. évi IV. törvény 33. §-a is.

\footnotetext{
${ }^{25}$ Erröl lásd részletesebben KovÁTs Andor: A büntetőjogi elévülés dogmatikája. Első füzet, Szeged-városi Nyomda, Szeged, 1922, 46-47.

${ }^{26}$ A bünvádi perrendtartásról szóló 1896. évi XXXIII. törvény (a továbbiakban: Bp.) 264. §-ának 2. pontja értelmében a Bp. szabályozta büntetőeljárás folyamán először a vádirat benyújtását követően a vádtanácsnak volt lehetősége a vádirat elutasítására és az eljárás megszüntetésére, ha elévülés következtében az eljárásnak nem volt helye. Ha a fötárgyalás során derült ki, hogy a bünvádi eljárás elévülés következtében nem folytatható, a bíróság a Bp. 352. § második bekezdése szerint felmentő ítéletet hozott.
} 
Az elévülésre vonatkozó rendelkezések a hatályos jogrendszerünkben a Btk. 2628. §-aiban találhatóak. A Btk. 26. § (1) bekezdése általánosságban ír a jogintézményröl, lefektetve, hogy - a Btk.-ban és külön törvényben meghatározott kivételekkel - az elévülés az absztrakt büntetési tétel felső határához igazodik, de legalább öt év.

A 2012-es Btk. az előző, 1978. évi Btk.-hoz képest sok tekintetben, így az elévülés normáiban is hozott némi változást. Ahogy a Btk. szabályozása kapcsán több tekintetben szigorodást láthatunk, ugyanez fedezhető fel az elévülés esetében is: az általános, minimális elévülési idő a korábbi három évről öt évre emelkedett.

A Btk. Különös Része az egyes bűncselekményeket szabadságvesztéssel vagy elzárással rendeli büntetni. Ez utóbbi esetben, ${ }^{27}$ mivel az általános részi szabályok [Btk. 46. § (1)] szerint annak leghosszabb tartama 90 nap, az elzárással büntetendő cselekmények elévülési ideje a minimum öt évhez igazodik. Szabadságvesztésnél a büntetési tételek felső határa egy év, két év, három év, illetve öt év lehet, így ezen büntetendő cselekmények esetében is az általános elévülési idő, vagyis az öt év rögzíthetö; az ennél hosszabb tartamú büntetések pedig mivel meghaladják az öt évet, az elévülést a Különös Részben meghatározott speciális maximum szabja meg: nyolc évnek, tíz évnek, tizenöt évnek, valamint húsz évnek megfelelő idő alatt évülnek el a további deliktumok.

A jogalkotó két kivételtől - a határzár megrongálásának halált okozó esetétől [Btk. 352/B. § (4)] és az embercsempészés szervezőjének vagy irányítójának felelősségét szabályozó bekezdéstől [Btk. 353. § (5)] - eltekintve a húsz évig terjedő szabadságvesztéssel is büntethető cselekmények esetében vagylagos büntetésként helyezi el az életfogytig tartó szabadságvesztést. Ezen esetekben az elévülés nem a húsz évhez, hanem az életfogytiglanhoz igazodik, amely pedig az el nem évülő bủncselekmények közé tartozik. Az említett két deliktum minősített esete viszont húsz év alatt évül el. ${ }^{28}$

Az általános elévülési szabályt rögzítő Btk. 26. § (1) bekezdése kivételekröl is említést tesz. E kivételek közé tartoznak egyrészről a XXVII. fejezetben szereplő korrupciós bủncselekmények, amelyek elévülési ideje tizenkét év, másrészt az el nem évülő büncselekmények.

${ }^{27}$ A Btk. Különös Része elzárással rendeli büntetni a következő deliktumokat: a méreggel visszaélés [188. § (1)]; a magántitok megsértésének [223. § (1)] és a levéltitok megsértésének [224. § (1)] alapesete; a minősített adattal visszaélésnek [265. § (2) a), (6)], illetve a hatóság félrevezetésének [271. § (3)] egyes esetei; a tanúvallomás jogosulatlan megtagadása [277. §]; a mentő körülmény elhallgatásának [281. § (3)] és a fogolyszökésnek [Btk. 283. § (3b)] egyes esetei; az önkényuralmi jelkép használata [335. §]; a közokirat-hamisítás gondatlan esete [342. § (3)]; a jogellenes bevándorlás elősegítése, támogatása elnevezésű bűncselekmény alapesete [Btk. 353/A. § (1)]; a járványügyi szabályszegés [361. §]; a készpénz-helyettesítő fizetési eszköz hamisításának előkészülete [392. § (2)]; a tiltott adatszerzés egyik esete [Btk. 422/A. § (1)]; a kötelességszegés szolgálatban elnevezésű bűncselekmény egyik gondatlan esete [438. § (4)]; valamint a parancs iránti engedetlenség alapesete [444. § (1)].

${ }^{28}$ A teljesség kedvéért szükséges megjegyezni, hogy szintén mellőzi a Btk. az életfogytig tartó szabadságvesztés vagylagos elhelyezését az 5 évtől 20 évig terjedő szabadságvesztéssel büntetendő szexuális erőszak egyik minősített esetében [Btk. 197. § (4a)], azonban mivel e deliktum sértettje 12. életévét be nem töltött személy (tehát 18 év alatti), ezért e bűncselekmény a Btk. 26. § (3) bekezdés c) pontja szerint el nem évülő büncselekménynek minősül. 
Az el nem évülő bűncselekmények is további két kategóriára oszthatók, annak megfelelően, hogy hol kerültek szabályozásra: egyik részüket a Btk. 26 . § (3) bekezdésében meghatározott tényállás-csoportok alkotják, másik részükre pedig az (1) bekezdés utal, akkor, amikor a kivételek között említi az egyes bűncselekmények elévülésének kizárásáról szóló törvényt.

Mindezek részletes áttekintése külön dolgozatot igényelne, így e rendelkezések további vizsgálatát jelen tanulmányomban nem ismertetem.

\section{A büntetőeljárási törvény}

Mielőtt rátérnék a korrekcionalizáció egykori gyakorlatának és az elévülésre vonatkozó hatályos rendelkezéseknek az összevetésére, szükséges még röviden szólni a büntetőeljárás néhány, az elévüléshez kapcsolódó rendelkezéséről avégett, hogy azt követően egy teljes kép birtokában végezhessem el elemzésemet.

Az anyagi jogi vizsgálódás mellett - a teljesség kedvéért - szükséges e kitekintés, hiszen az elévülés kettős természettel rendelkezve, egyszerre anyagi és alaki jogi vonásokat is magán hordoz. ${ }^{29}$ Részletszabályait a Btk.-ban találjuk meg, ugyanis a „büntethetőség elévülése alapvetően [mégiscsak] anyagi jellegü jogintézmény”, ${ }^{30}$ azonban annak az érvényre jutásához szükséges rendelkezéseket a büntetőeljárásról szóló 2017. évi XC. törvény (a továbbiakban: Be.) határozza meg.

A büntethetőséget megszüntető elévülés a büntetőeljárás valamennyi szakaszában érvényre juthat: az eljárás során bármikor észlelik azt a hatóságok, az elévülés azt eredményezi, hogy a büntetőeljárás vagy meg sem indul, vagy a folyamatban lévő eljárás megszüntetésre kerül. Tanulmányomban a nyomozási szakban felismert elévülést teszem a további vizsgálat tárgyává.

\subsection{Az elévülés a nyomozási szakban}

A büntetőeljárás nyomozási szakaszának alapvető jelentősége rögzíthető az eljárás további kimenetelét illetően. „A nyomozásnak kettős feladata van, egyrészt kiszüri azokat az ügyeket, amelyek bizonyithatatlanok, büntethetőséget kizáró vagy megszüntető ok áll fenn, így nem alkalmasak a bírói eljárásra [...]. Másrészt, a szükséges eljárási cselekmények elvégzésével, a bizonyítással biztositja az alapot a bírósági eljárásnak." 31

A törvénybe ütköző magatartás elkövetése miatt indult büntetőeljárásban legkorábban a feljelentés megtételekor észlelhető, hogy a feljelentett által elkövetett cselekmény már elévült. Erre az esetre nézve a Be. 381. §-a (1) bekezdésének $d$ ) pontja kimondja, hogy az ügyészség és a nyomozó hatóság a feljelentést elutasítja,

\footnotetext{
${ }^{29}$ Az elévülés kettős karakterét jól mutatja, hogy mind anyagi jogi, mind eljárásjogi művek egyaránt tárgyalják a jogintézményt.

30 Belovics [et al.]: i. m., 248.

${ }^{31}$ GótH Kármen: A nyomozás folytatása a nyomozási bíró előtti eljárásban. Ügyészek Lapja, 2008/3, 39.
} 
feltéve, hogy a rendelkezésére álló adatokból kitűnik, a büntethetőség halál, elévülés vagy kegyelem folytán megszünt.

A nyomozó hatóság, illetve a felügyeletét és irányítását ellátó ${ }^{32}$ ügyészség a feljelentés alapjául szolgáló cselekményt minősítve meg tudja állapítani büntetési tételének felső határát, melyhez az elévülési idő is igazodik. Amennyiben a deliktum elkövetése óta az elévülési idő már eltelt, és a rendelkezésre álló adatokból az is látszik, hogy nem állt fenn olyan körülmény, amely az elévülést félbeszakította volna, vagy olyan időtartam, amely az elévülési időbe nem számított volna be, megállapítható a büntethetőség elévülése, és emiatt a feljelentés elutasításra kerülhet.

Előfordulhat, hogy a nyomozó hatóság, illetve az ügyészség számára a feljelentés megtételekor nem állt rendelkezésre minden adat a cselekmény elévülése vonatkozásában, ezért nem volt megállapítható annak elévülése; vagy ugyan konstatálható lett volna, de az a hatóságok figyelmét elkerülte, ennélfogva az ügyészség vagy a nyomozó hatóság a nyomozást elrendelte. A hatóság a nyomozás során a felkutatott bizonyítékok közvetlen tanulmányozásával, illetve közvetett módon, például a bizonyítékokat szolgáltató személyek kikérdezésével tehet szert az eljárás tárgyává tett cselekménnyel kapcsolatos ismeretekre, így az elkövetés pontosabb idejére is. ${ }^{33}$ Ekkor kerülhet abba a helyzetbe, hogy e körülmények megfelelö értékelésével észlelje tévedését. Ez esetben - ha a büntethetőség elévülés folytán megszűnt a Be. 398. §-a (1) bekezdésének e) pontja alapján megszünteti az eljárást. E körbe tartozhat az az eset is, amikor a nyomozás során merülnek fel olyan újabb körülmények, információk, amelyek alapján a cselekményt eltérően kell minősíteni, és így megállapítható, hogy az új minősítés szerinti büntetési tételhez igazodó elévülési idő már eltelt.

\subsection{A nyomozás során hozott téves döntés orvoslása - a panasz}

Számolnunk kell azzal a lehetőséggel, hogy az ügyészség vagy a nyomozóhatóság a nyomozás során téves döntést hoz az elévüléssel összefüggésben. Megeshet, hogy egy feljelentés alapján olyan ügyben rendel el nyomozást, amelyben az elkövető büntethetősége már megszűnt. Nem elképzelhetetlen, hiszen a „nyomozó hatóságnak a büncselekményről mint lezajlott történésről származó kezdeti értesülései [...] többnyire szinte szükségképpen csak hiányosak vagy hézagosak lehetnek. ${ }^{\prime 34}$ Ebben az esetben ugyanakkor jelentősebb jogsérelem nem történik, hiszen a tévedés - legkésőbb a bírói szakban - még kijavítható az eljárás megszüntetésével. A fordított esetre érdemes azonban odafigyelnünk: arra, amikor az ügyészség vagy a nyomozó hatóság elévülésre hivatkozva a feljelentést elutasítja vagy a nyomozás megszünteti, miközben a büntethetőség még nem évült el.

32 FANTOLY Zsanett: Megváltozott ügyészi szerepfelfogás az új magyar büntetőeljárási törvényben. Erdélyi Jogélet, 2021/1, 57-67. (doi: 10.47745/ERJOG.2021.01.06) 
Ez leginkább akkor fordulhat elő, ha nem megfelelően kerül minősítésre az elkövetési magatartás, és egy olyan bủncselekmény kerül a büntetőeljárás tárgyaként megjelölésre, amely alacsonyabb büntetési tétellel büntetendő - így rövidebb elévülési idővel rendelkezik -, mint ahogy a cselekmény valójában a törvény szerint minősülne.

A téves döntés helyesbítése a Be. 400. §-a alapján megtörténhet, ugyanis itt rendelkezik a jogalkotó a megszüntetett eljárás folytatásáról, így arról az esetkörről is, amikor az eljárást elévülés miatt szüntette meg az ügyészség vagy a nyomozó hatóság. Az említett törvényhely kimondja, hogy az eljárás megszüntetése nem akadálya annak, hogy ugyanabban az ügyben utóbb az eljárást folytassák, az erről szóló határozat ellen jogorvoslatnak nincs helye.

Ha a hatóságok nem észlelnék tévedésüket, és hivatalból nem folytatnák az eljárást, a Be. 369. § (1) bekezdése biztosítja, hogy az ügyészség, illetve a nyomozó hatóság vele közölt határozata ellen panaszt terjesszen elő a gyanúsított, a bủncselekmény elkövetésével megalapozottan gyanúsítható személy, a védője, a sértett, a vagyoni érdekelt és az egyéb érdekelt. Az eljárást elévülés miatt megszüntető határozat nyilvánvalóan a sértettnek adhat okot panasz benyújtására. A (2) bekezdés ugyanezt a jogot a feljelentő számára is biztosítja a feljelentés elutasítása miatt.

A panasz elbírálásáról a Be. 370. §-a rendelkezik: a határozatot hozó ügyészség vagy nyomozó hatóság a határozatát saját hatáskörben is hatályon kívül helyezheti, vagy azt megváltoztathatja, ha a panaszt alaposnak tartja. Amennyiben a panaszt nem tartja alaposnak, az ügyiratokat a panaszra vonatkozó nyilatkozatával együtt felterjeszti: a határozatot hozó ügyészség a felettes ügyészséghez, a nyomozó hatóság az illetékes ügyészséghez. Ha a panaszt elbíráló ügyészség a panaszt alaposnak tartja, a határozatot hatályon kívül helyezi vagy megváltoztatja, ellenkező esetben a panaszt elutasítja. A panaszt elbíráló határozat ellen további panasznak nincs helye.

Ha a panasszal nem sikerül elérni azt, hogy az igazságszolgáltatás gépezete müködésbe lendüljön, a sértett a Be. CV. fejezetében szabályozott pótmagánvádas eljárásban pótmagánvádlóként léphet fel, azonban ezt csak a törvényi feltételek fennállta esetén teheti meg. Nincs helye pótmagánvádlóként történő fellépésnek (többek között), ha a terhelt fiatalkorú, vagy ha a bủncselekmény a sértett jogát vagy jogos érdekét közvetlenül nem sértette vagy veszélyeztette, illetve abban az esetben, ha a deliktumnak egyáltalán nincs sértettje, hiszen akkor nincs, aki pótmagánvádlóként felléphetne. Ráadásul - ha van helye pótmagánvádlóként való fellépésnek - azt a sértett főszabály szerint a panaszt elutasító határozat közlésétől számított két hónapon belül teheti meg, ezt követően erre nincs lehetőség.

Itt szükséges még megemlíteni, hogy a panaszt elutasító határozat ellen, habár korlátozott esetben, a Be. 374. § (1) bekezdése alapján lehet helye felülbírálatnak - az e) pont szerint ugyanis felülbírálati indítvány terjeszthető elő, ha az ügyészség, illetve a felettes ügyészség elutasította az ea)-ee) alpontokban meghatározottakat sérelmező panaszt -, ámde az elévülés miatt elutasított feljelentés és megszüntetett nyomozás nem tartozik az ea)-ee) alpontokban nevesítettek közé. Így ezen esetekben a bírósághoz felülbírálat címén nem lehet fordulni. 
A Be. 400. § (5) bekezdése alapján a nyomozást folytatni - ha azt elévülés miatt szüntették meg és hivatalból vagy panasz alapján az eljárás folytatására hat hónapon belül nem került sor - az ügyészség indítványára, csak a bíróság döntése alapján lehet.

Mindez komolyabb problémát akkor okozhat, ha elévülésre hivatkozva már nyomozási szakban megszüntetésre kerül az eljárás anélkül, hogy a cselekmény ténylegesen elévült volna. Amennyiben az ügyészség maga nem rendeli el a nyomozás folytatását, vagy azt 6 hónap elmúltával nem indítványozza a bíróság előtt, és pótmagánvádnak - bármely okból - nincs helye, vagy az arra nyitva álló határidő is eltelt, az ügy - a büncselekmény helytálló minősítése végett - sosem kerül bíróság elé.

\section{Konklúzió - de lege ferenda javaslattal}

A jogtörténeti részben felvázolt, elévülésre vonatkozó rendelkezéseket, a jogintézmény hatályos szabályozását, illetve annak érvényesülését biztosító Be.-beli szakaszokat röviden a következőképpen foglalhatjuk össze.

Az 1878. évi V. törvénycikk alapján a korrekcionalizációból kifolyólag a büntethetőség elévülése a kiszabandó konkrét büntetéshez igazodott, így az eljárásnak a bírósági szakaszig el kellett jutnia, hogy e kérdésben bíró dönthessen. A büntetőeljárás jelenlegi modellje ehhez képest egyszerübb képet fest: az elévülés kérdésében nem szükséges a büntetőeljárásnak egészen a bírói szakig eljutnia, hisz az eljárást már a nyomozó hatóság, illetve az ügyészség is megszüntetheti elévülés okán, ugyanis annak Btk.-beli határideje főszabály szerint az absztrakt büntetési tétel felső határához igazodik. Ebből fakadóan tehát nincs szükség a bizonyítékok mérlegelésére, az enyhítő és súlyosító körülmények figyelembevételére és egy kiszabandó büntetés valószínüsítésére, elegendő csak annak a megállapítása, hogy a bủncselekmény elkövetésétöl - figyelembe véve az elévülés félbeszakítását és nyugvását megalapozó körülményeket - a meghatározott idő már eltelt, és így a cselekmény elévült.

Mivel az eljárási elévülés az egyes tényállások büntetési tételének felső határához igazodik, alapvető jelentőségű az adott cselekmény minősítése. Annak eldöntése, hogy az elkövetési magatartás a konkrét deliktum alapesetét vagy egy súlyosabb büntetési tétellel rendelkező minősített esetét valósította-e meg, esetleg egészen más bűncselekmény valósult meg, lényeges kérdés, hiszen az elévülés határidejét határozza meg. Ez különösen meghatározóvá akkor válik, ha a büntetőeljárás nem jut el a bírói szakba, hanem a nyomozó hatóság vagy az ügyészség elévülés okán megszünteti azt. Mindez felvethet bizonyos aggályokat, hiszen az igazságszolgáltatásért felelős bíróság döntése híján e hatóságoknak kell a cselekmény minősülése kérdésében véglegesen állást foglalni, és esetleg az eljárás megszüntetéséről dönteni. ${ }^{35}$

35 Természetesen felmerülhet, hogy a többi büntethetőségi akadály, különösen a büntethetőséget kizáró vagy korlátozó okok esetében hasonló problémába nem ütközünk-e (hiszen ezekre hivatkozással a nyomozó hatóság a feljelentést elutasíthatja, illetve az ügyészség a nyomozást megszüntetheti). Azon túlmenően, 
A büncselekmény minősüléséről alapesetben a végső döntést a bíróság hozza meg. Ha az eljáró bíró a bủncselekmény vádirati minősítésétől eltér, a bírói gyakorlat egyértelmüen amellett foglal állást, hogy ez az elévülési időre is kihatással van: az nem a vádirat szerinti, hanem a bíróság általi minősítéshez fog igazodni. A Kúria (korábban Legfelsőbb Bíróság) több elvi jelentőségủ bírósági határozatában is erre mutatott rá. ${ }^{36} \mathrm{~A}$ legföbb bírói fórum akként rögzítette ezt, hogy „az elévülés mindenkor az adott cselekmény anyagi jogszabályoknak megfelelő törvényes minősítéséhez igazodik", és mindez igaz akkor is, ha a vádirat másként minősíti az elkövetett cselekményt, illetve ha az alsóbb fokú bíróság sem ismeri fel helyesen azt. ${ }^{37}$

Egy gondolat erejéig szükséges kitérni arra is, hogy a többi büntethetőséget megszüntető ok esetében hasonló mérlegelési probléma fel sem merülhet: hiszen ha az elkövető meghalt, azt halotti anyakönyvi kivonat bizonyítja; ha kegyelemben részesült, arról a hatóságok rendelkezésére áll egy köztársasági elnöki határozat vagy éppen törvény explicit rendelkezése; a tevékeny megbánás esetében közvetítői eljárás keretében születik egy megállapodás; továbbá a törvényben szabályozott egyéb okok esetében is dokumentáció bizonyítja, hogy az elkövető büntethetősége megszünt. Ezen okok - a büntetőeljárás megszüntetése körében - egyszerüen eldönthető ténykérdések, amelyek nem igényelnek mérlegelést, szemben a cselekmény minősítését megkívánó elévüléssel. ${ }^{38} \mathrm{Az}$ összes többi büntethetőséget megszüntető ok e szempontból eltér az elévüléstől, ebből kifolyólag ezeknél nem is indokolt a nyomozás megszüntetéséről a bíróságnak határoznia. Nem így az elévülés esetében.

$A z$ 1878. évi Btk. hatálya alatt alkalmazott rendszerrel való összevetés - amelyben minden esetben a bírónak kellett döntenie az elévülés kérdésében - mutat rá igazán a hatályos szabályozás hiányosságára.

Ha a nyomozó hatóság vagy az ügyészség nem törvényesen minősíti az elkövetett cselekményt, akkor nem a megfelelő búncselekmény büntetési tételének felső

\footnotetext{
hogy e kérdés megválaszolása - annak terjedelme okán - külön tanulmány témája lehetne, ismert, hogy a büntethetőséget kizáró okok között is igen szerteágazó „típusú” büntethetőségi akadályokkal találkozunk. Így ezek összehasonlítása és jelen dolgozattal való összevetése külön figyelmet igényelne, amely meghaladta e tanulmány kereteit. Részben igaz, hogy a kizáró okok kapcsán is van, amikor bonyolult jogi mérlegelést szükséges végezni (így e tekintetben is felmerülhet, hogy ezt nem ugyanúgy bíróságnak kellene-e elvégeznie), de emellett azt is látnunk kell, hogy e mérlegelés egyébként is gyakorta a bíróság előtt történik. Mi sem támasztja ezt jobban alá, mint a büntethetőségi akadályok körében született elvi jelentőségủ bírósági határozatok (BH-k és EBH-k) nagy száma.

${ }^{36}$ Lásd például EBH2008. 1764.

${ }^{37} \mathrm{BH} 2012.86$. Ugyanígy: BH2018. 324.

${ }^{38}$ E megállapítás alól részben kivételt képezhet a Be. LXVII. Fejezetében szabályozott feltételes ügyészi felfüggesztés, amelynek eredményes eltelte a Be. 420. § (1) bekezdése értelmében büntethetőséget megszüntető ok. A feltételes ügyészi felfüggesztésnek akkor van helye, ha az alapul szolgáló büncselekmény 3 évi, kivételesen 5 évi szabadságvesztéssel büntetendő - ez esetben szintén számításba jön a cselekmény minősítése, de a jogintézmény alapvetően kisebb súlyú deliktumok esetében kerülhet szóba. Emiatt eshet más megítélés alá, mint az elévülés, hiszen a minimális öt éves elévülési idő miatt az ennél kisebb súlyú bủncselekmények minősítése - az elévülés szempontjából - nem releváns. Ezenfelül a feltételes ügyészi felfüggesztésnél az ügyészség magatartási szabályt vagy kötelezettséget is előírhat, melyek tanúsítása szükséges a felfüggesztés tartamának eredményes elteltéhez (és így a büntethetőséget megszüntető ok bekövetkezéséhez): az eredményességhez szükséges magatartás tanúsítása, illetve az előírt idő letelte pedig ugyancsak objektíven megállapítható körülmények.
} 
határát fogja alapul venni, amikor azt vizsgálja, hogy elévült-e már a deliktum. Emiatt előfordulhat, hogy az eljárás úgy kerül megszüntetésre, hogy a tényleges megvalósult cselekmény még nem évült el. A cselekmény minősítése kérdésében a bíróságnak kellene döntenie, mivel jelenleg, ha a nyomozás során az eljárást elévülés miatt megszüntetik, a megszüntetésről szóló határozat ugyan panasszal megtámadható, illetve az eljárás hivatalból vagy panasz alapján folytatható, de ha az utóbbi nem történik meg, az előbbi esetén is a panaszt csak az ügyészség vagy a felettes ügyészség bírálja el, a megszüntetésröl - és az elévülésről - való döntés nem feltétlenül kerül bíróság elé.

Éppen ezért szükséges lenne a Be. hatályos szabályainak a módosítása, amely két irányban is elképzelhető. Mindkét javaslat lényege, hogy a nyomozási szakban a büntetőeljárás elévülés miatt történő megszüntetéséről végső soron a bíróság döntsön.

Egyfelől a szabályozás javítható oly módon, hogy az eljárást megszüntető vagy feljelentést elutasító határozatot a nyomozási szak általános jogorvoslati formája, a határozat elleni panasz helyett közvetlenül a Be. 374. §-a szerinti felülbírálati indítvánnyal lehessen megtámadni. Ezzel biztosítható lenne, hogy a hatóság által tévesen minősített cselekmény - ebből fakadóan téves - elévülésére hivatkozással elutasított feljelentés vagy megszüntetett eljárás folytatódjon. Az elévülés kérdéséröl így végső soron a cselekmény törvényes minősítésére hivatott bíróság döntene, és kiküszöbölhetők lennének a téves minősítések. E megoldást elsősorban a feljelentés elutasítása esetén tartanám célravezetőnek, ugyanis a módosítás problematikus lehet azon bủncselekmények esetében, amelyeknek nincs sértettje, hiszen így nincs, aki a megszüntető határozat ellen jogorvoslattal élhetne. ${ }^{39}$

Másrészről az elévülés e részletének megreformálása történhet úgy is, hogy a nyomozási szakban járó büntetőeljárás elévülés okán történő megszüntetéséről ne az ügyészség vagy a nyomozó hatóság, hanem minden esetben a nyomozási bíró döntsön már elsőfokon is. A megoldás mellett szól, hogy ily módon a bíróság vizsgálhatja a cselekmény minősítését, és szükség esetén eltérhet a nyomozás tárgyává tett minősítéstől. Ha pedig a nyomozási bíró sem megfelelően minősítené a cselekményt, a határozat fellebbezéssel megtámadható, így egy téves minősítés másodfokon korrigálható.

Megfogalmazódhat ellenérvként, hogy mivel az ügyész tudta és akarata nélkül nincs nyomozás, aggályos lehet, „ha a bíróság [az ügyész eljárást megszüntető határozatát követően] - az ügyész »akarata» ellenére - [mégis] nyomozásra kötelezhetné az ügyészt, s rajta keresztül a nyomozó hatóságot." ${ }^{40}$ Ugyanakkor a felvázolt módosítási javaslattal e problémának elébe mennénk: az eljárás elévülés miatti megszüntetéséről való döntést a nyomozási bíró hatáskörébe utalva - csakúgy, mint a Be. 400. $§(5)$ bekezdés szerinti eljárás folytatásáról szóló döntésnél - nem az ügyészség döntését írná felül a bírósági határozat, hanem a kérdésben közvetlenül

${ }^{39}$ Erre világít rá NÁNÁsı Gábor: A nyomozás során hozott határozatok elleni panaszról, középpontban a központi államigazgatási szervek jogorvoslati jogával. Magyar Jog, 2016/5, 303.

40 VIDOR László: A nyomozás folytatásáról - különös tekintettel a Be. 191. § (3) bekezdésében foglaltakra. Magyar Jog, 2005/5, 269. 
a bíróság döntene. A nyomozás folytatásánál ennek garanciális jelentősége van hasonló okokból ezt indokolt lenne a megszüntetésnél is biztosítani.

Bármelyik megoldás mellett is tesszük le a voksunkat, a végső cél nem lehet más, mint a Be. preambulumában is megfogalmazott elv, az igazság megállapításának szem előtt tartása, valamint az, hogy az elévülés anyagi jogi szabályai a törvényes minősítésnek megfelelően jussanak érvényre.

Mert bár - szemben a Csemegi-kódexszel - az egyszerüsítést szolgáló, észszerū indokai vannak annak, hogy az elévülésről nem szükséges minden esetben bíróságnak döntenie, ugyanakkor a de lege ferenda javaslat szerinti változtatás se tenné sokkal bonyolultabbá a szabályozást, miközben fontos - korábban meglévő - garanciális elemeket építene vissza a rendszerbe. A jelenlegi szabályozás olyan helyzetet is eredményezhet, ami egy téves minősítés miatt úgy akadályozza meg az elkövető büntetőjogi felelősségre vonását, ahogyan annak helyes bűncselekményi minősítéssel nem lenne helye. A bírósághoz fordulás lehetőségének hiánya miatt egy téves minősítésből fakadó téves döntés pedig jelenleg nem javítható ki. Ennek orvoslására nyújthatnak megoldást a fenti javaslatok. 